\author{
I.I. ЧEPHEHKO, I.A. ЧУXHO
}

\title{
ЕПІДЕМІОЛОГІЧНІ ТА КЛІНІЧНІ АСПЕКТИ НАСЛІДКІВ ЧЕРЕПНО-МОЗКОВОЇ ТРАВМИ
}

\author{
Харківський національний медичний університет, м. Харків, Україна
}

\begin{abstract}
Мета: провести дослідження поширеності черепно-мозкової травми та їі основних наслідків на основі вивчення літературних джерел, їх впливу на якість життя хворих, соціальну значимість цих наслідків 3 урахуванням розповсюдженості патології.

Матеріали і методи. У дослідженні використовували бібліосемантичний та аналітичний методи, метод наукового абстрагування. Були досліджені статистичні дані та наукові публікації щодо розповсюдженості та наслідків черепномозкових травм, їх віддалених наслідків та особливостей реабілітації.

Результати. Проведений аналіз розповсюдженості черепно-мозкових травм, їх віддалених наслідків дозволяє констатувати зростання значимості цієї проблеми на сучасному етапі розвитку держави, а їх вплив на якість життя хворих, складнощі в їх подальшій соціальній адаптації щодо зростання медико-соціальної значимості цієї проблеми.

Висновки. Внаслідок зростання кількості військових конфлліктів у світі та розвитку військових технологій спостерігається тенденція до зростання кількості черепно-мозкових травм. Удосконалення підходів до лікування цих травм дозволило збільшити рівень виживання хворих, проте внаслідок цього зросла і медико-соціальна значимість удосконалення системи лікування віддалених їх наслідків, що внаслідок значного рівня неврологічних, когнітивних та адаптаційних порушень, мають значний негативний вплив на якість життя хворих та їх оточення, викликаючи негативні соціальні наслідки для суспільства вцілому.
\end{abstract}

КЛЮчОВІ СЛОВА: черепно-мозкова травма; медико-соціальні наслідки.

Велика питома вага черепно-мозкового травматизму, висока летальність та інвалідизація постраждалих, фрактичне збільшення чисельності нейротравм, невтішні дані довгострокових прогнозів виводять проблему нейротравматизму в розряд пріоритетних [12, 13, 16, 19, 20]. Дані епідеміологічних досліджень протягом останніх 25 років показали, що в загальній структурі травматизму ушкодження центральної нервової системи складають до 30-40 \%, а серед причин інвалідизації населення, що настали внаслідок усіх травм, вони виходять на перше місце і складають 25-30 \% [6, 13-15]. Епідеміологічне вивчення черепно-мозкової травми (ЧМТ) свідчить про iï значну поширеність [5]. Зменшення кількості померлих та постраждалих при травмах має важливе соціально-економічне значення і сприятиме покращенню демографрічних показників [9-11].

Мета роботи: провести дослідження поширеності черепно-мозкової травми та її основних наслідків на основі вивчення літературних джерел, їх впливу на якість життя хворих, соціальну значимість цих наслідків з урахуванням розповсюдженості патології.

Матеріали і методи. У дослідженні використовували бібліосемантичний та аналітичний методи, метод наукового абстрагування. Були досліджені статистичні дані та наукові публікації щодо розповсюдженості та наслідків черепно-мозкових

(c) I.I. Черненко, І.А. Чухно, 2017 травм, їх віддалених наслідків та особливостей реабілітації.

Результати дослідження та їх обговорення. Травматичні ушкодження черепа та головного мозку складають 30-40 \% усіх травм і займають перше місце за показниками летальності та інвалідизації серед осіб працездатного віку. За даними Всесвітньої організації охорони здоров'я, щорічно в світі отримують черепно-мозкову травму понад 10 млн осіб. Поширеність всіх травм, отруєнь та деякі інші наслідки дії зовнішніх причин в Україні серед всього населення в 2007 р. складала 5192,5 на 100 тис. населення, в 2012 р. - 4997,0 на 100 тис. населення, 3 них 4708,0 на 100 тис. населення 3 діагнозом встановленим вперше в житті. ЧМТ щорічно становить у різних регіонах України від 2,3 до 6 випадків (у середньому 4-4,2) на 1000 населення.

У 2012 р. смертність від зовнішніх причин серед міського населення дорівнювала 82,6 на 100 тис., серед сільського - 111,6 на 100 тис. На сільську місцевість припадає 1/3 всіх ЧМТ. Щорічно в світі від черепно-мозкової травми гине близько 1,5 млн осіб і більше ніж 2,4 млн стає інвалідами. Підтвердженням цього $є$ кількість померлих від травм на 100 тис. населення: у США - 56, Англії - 50-56, Польщі - 75, Угорщині - 115, Україні - 132 [11, 14, 16]. Щодня в Європейському регіоні через травми гине понад 2000 осіб, 60 тис. потрапляють у лікарні та 600 тис. звертаються за амбулаторною 
допомогою. Травми є основною причиною смерті серед людей віком до 45 років [9, 10].

Середня вартість надання медико-санітарної допомоги в Європі становить 1250-7250 євро на одну смертельну травму і 4800-12000 євро на одну несмертельну травму, відповідно, від 1 до 6 млрд євро витрачається щорічно на смертельні травми і від 80 до 290 млрд євро на лікування несмертельних травм [20]. Використовуючи досвід країн Європи з найменшою кількістю травм, можна було б запобігти 68 \% травм, тобто щорічно врятовувати до 500 тис. життів [9, 20]. В Європейському регіоні у 2002 р. травми спричинили смерть близько 800 тис. людей (8,3 \% усіх смертей). Причому одна третина смертей від травм припадає на вік 30-44 роки. Від травм чоловіки помирають у трьох випадках із чотирьох $[5,12]$.

За кордоном протягом останніх 25 років опубліковано цілу низку робіт з епідеміології ЧМТ [10, 14]. Дослідження закордонних авторів показали, що серед постраждалих із ЧМТ різного ступеня тяжкості близько 30 \% гине на догоспітальному етапі, а з кількості госпіталізованих від 20 до $30 \%$ помирає у відділеннях стаціонарів, ще 10-20\% залишаються «глибокими» інвалідами. Тільки 50-60 \% хворих, які були виписані зі стаціонарів, повністю відновлюються або зберігаються мінімальні неврологічні симптоми та порушення [20].

У структурі ЧМТ домінує струс головного мозку - від 81 до 90 \%. Забої головного мозку різного ступеня тяжкості діагностуються від 5 до 13 \% від кількості усіх постраждалих із ЧМТ. Хворі з легкою ЧМТ складають близько 80 \% від загальної кількості госпіталізованих із приводу чМТ. На забої головного мозку середнього та тяжкого ступенів припадає від 30 до 50 \%. Стиснення головного мозку травматичними внутрішньочерепними гематомами та гідромами в структурі чМТ складають від 1 до 9 \% [10, 18, 19]. Загалом забої та стиснення головного мозку спостерігають з частотою 30-40 випадків на 100 тис. населення. При цьому питома вага забоїв та стиснення головного мозку в чоловіків вища, ніж у жінок [8]. 3 віком частка більш тяжких клінічних форм чМТ зростала як у чоловіків, так і у жінок. Висока летальність від чМТ склала у віці від 50 років і старше (23,06 \%), в наступні вікові періоди летальність зростала, та досягала максимуму в віці 90 років і старше $(44,4 \%)$ [9].

Почастішання в останні десятиліття локальних військових конфрліктів призвело до збільшення випадків бойових травматичних ушкоджень головного мозку (бойова черепно-мозкова травма), які переважають у структурі бойових ушкоджень головного мозку $[10,19]$. Надзвичайно висока поширеність і неухильне зростання числа черепномозкових травм, високий відсоток ускладнень, інвалідизації великих груп населення зумовлюють актуальність вивчення цієї медичної та соціальної проблеми [10] та розробку заходів з удосконалення моделі надання медичної допомоги цим хворим.

Таким чином, основну увагу при травмі головного мозку приділяли саме неврологічній симптоматиці. У гострий період вибухової травми більше ніж у 85 \% постраждалих реєстрували порушення функції вегетативної нервової системи, синкопальні стани, ознаки симпатико-адреналового гіпертонусу - головний біль, підвищення артеріального тиску, тахікардія, ознобоподібні гіперкінези, підвищена тривожність $[10,18]$. При вибуховій травмі легкого та середнього ступенів тяжкості відзначали безліч розладів отоневрологічного, нейроофтальмологічного і терапевтичного характеру. Логоневротичні реакції і сурдомутизм спостерігали у 32,6 \% пацієнтів. Клінічні ознаки травми вестибулярного апарату, системні запаморочення з вегетативною симптоматикою, синдром Меньєра, за даними деяких авторів [6, 18], у період як самої Великої Вітчизняної війни, так і в найближчі післявоєнні роки, спостерігали у $14 \%$, а при додаткових дослідженнях із застосуванням фрункціональних навантажень - у 37 \% уражених.

Травматична енцесралопатія при непроникаючих пораненнях голови склала не менше $7 \%$, при проникаючих - вже 8,9 \%. Вона розвивалася через 1-2 роки після поранення і характеризувалася значним числом пограничних психічних розладів і зниженням інтелектуальних фрункцій [15]. Зміни особистості, зниження пізнавальних здібностей і передчасне старіння організму, що спостерігали у ветеранів в середині XX століття, пояснювали розвитком «метаболічного самоотруєння», що викликає «токсичну енцефалопатію». Тим не менше, тяжкі психічні розлади після закритої травми мозку через 7 років після закінчення війни виявляли тільки у 0,7\% хворих, а при відкритих, проникаючих чМТ, через той самий строк не діагностували взагалі [14]. Це складно пояснити з позицій сучасних поглядів на травматичну хворобу мозку, крім того, фракт наявності тяжкої психопатологічної симптоматики при госпіталізації в госпіталь всього у 1,1 \% постраждалих змушує сумніватися в істинності статистичних даних. Травматичну епілепсію реєстрували до 8,2 \% у всіх поранених у голову [16], але ці дані також суперечливі [19].

Повітряна контузія головного мозку становила 9,1 \% усіх закритих ЧМТ [16]. Кількість контужених вибуховою хвилею зростала з кожним роком війни в міру збільшення щільності вогню на одиницю площі. За даними інших джерел [18], кількість осіб із контузією на 1000 чоловік особового складу становила в перший, другий і третій роки Великої Вітчизняної війни, відповідно, 15,7; 25,8 і 39,4. Кількість постраждалих від вибухової хвилі значно збільшувалася в період важких оборонних боїв, а також у боях за оволодіння довготривалими укріпленнями супротивника, насиченими артилерією [15]. 
У зв'язку 3 постійним вдосконаленням засобів збройної боротьби кожна нова війна або великий збройний конфлікт не схожі на попередні, хоча й мають ряд схожих моментів. Не є винятком у цьому відношенні і події в Асрганістані. Відмінною рисою великомасштабних бойових операцій було широке застосування диверсійних актів із масовим використанням як протипіхотного, так і протитранспортного мінного озброєння $[10,13,14]$.

Застосування сучасних вибухових речовин, що володіють відмінними від раніше використовуваного тротилу і його аналогів бризантних властивостей, призвело до того, що поняття «закрита ЧМТ» розширилося до поняття «бойова закрита травма організму 3 наявністю великих поліорганних ушкоджень» $[6,18]$. Все це визначає високий відсоток летальності, складність у медичному обслуговуванні постраждалих в Афрганістані. За літературними даними [16], під час воєн початку минулого століття в загальній структурі санітарних втрат частка вогнепальних поранень голови досягала 11,0-15,0 \%, а частота ушкоджень хребта становила 3-4 \%.

Під час Великої Вітчизняної війни поранення голови, шиї та хребта становили від 11,9 до 16 \%, а закриті травми голови і шиї відносно загального числа закритих ушкоджень склали 11,4 \%, причому серед закритих травм тяжкі травми черепа і головного мозку склали 1,8 \%, легкі і середні ЧМТ - 80,9 \%. У загальній структурі ЧМТ, струсу головного мозку склали 70,9 \%, забої мозку легкого ступеня - 10,1 \%, забої мозку середнього ступеня - 2,7 \%, забої тяжкого ступеня - 1,3 \%, стиснення мозку на тлі тяжких забоїв - 3,1 \% [4, 13, 16].

Порушення регулюючого впливу нервової системи на процеси, що забезпечують адекватне пристосування організму до мінливих умов зовнішнього середовища, лежить в основі порушень компенсаторно-адаптивних процесів у резидуальний період черепно-мозкової травми $[11,19]$. Однак роль бойової черепно-мозкової травми у запуску механізмів адаптаційних порушень організму залишається недостатньо дослідженою. Разом з тим, розкриття цього питання в перспективі дозволить перейти до підвищення адаптаційних можливостей в осіб, які перенесли бойові черепно-мозкові травми різного ступеня тяжкості. Одним із нових критеріїв ефективності лікування і реабілітаційних заходів, які отримали в останні роки широке поширення в країнах із високим рівнем розвитку медицини, є оцінка якості життя (ЯЖ). Являє собою інтегральну характеристику фрізичного, психологічного, емоційного та соціального функціонування хворого та основана на його суб'єктивному сприйнятті.

Віддалені наслідки, як і сам фракт бойової черепно-мозкової травми, призводять до виражених фрункціональних порушень, психологічних проблем і соціальних обмежень, що значно погіршують якість життя пацієнтів. ЯЖ, будучи інтегральною характеристикою різних сорер функціонування людини, в медичному розумінні цього терміна завжди пов'язана зі здоров'ям. Вона є одним із ключових понять сучасної медицини, що дозволяє проводити аналіз складових життєдіяльності людини відповідно до критеріїв Всесвітньої організації охорони здоров'я. Концепція дослідження якості життя в медицині ґрунтується на єдиних методологічних підходах, що включають три основних принципи: багатомірність оцінки, змінюваність параметрів ЯЖ у часі і участь хворого в оцінці свого стану.

Інструменти оцінки (загальні та специфрічні фрорми), розроблені експертами провідних світових клінічних центрів відповідно до принципів доказової медицини і вимог Good Clinical Practics (GCP), створили можливість кількісної оцінки основних сорер життєдіяльності людини. Застосування їх разом 3 іншими загальноприйнятими клінічними, лабораторними й інструментальними методами дослідження дозволяє розширити уявлення лікаря про стан хворого в цілому. Загальні опитувальники вимірюють широкий спектр функцій сприйняття здоров'я і використовуються для порівняння ЯЖ пацієнтів, які страждають від різних захворювань, а також для їі оцінки в популяції, тоді як специфічні інструменти орієнтовані здебільшого на проблеми, пов'язані з певними захворюваннями.

Віддалені наслідки бойової ЧМТ мають різноманітний спектр порушень усіх сорер життєдіяльності організму, насамперед фрізичної або фрункціональної, яка визначає індивідуальний рівень якості життя хворого. Кількісне визначення функціонального стану цієї групи хворих є досить складним завданням, оскільки визначається ставленням хворого до виконання не тільки професійних, непрофесійних обов'язків, але і соціальною адаптацією. Тим не менше, і в цьому випадку оцінка функціональної активності пацієнта схематична і не виражається кількісно, що робить дуже складним оцінку змін фрункціонального статусу хворих у динаміці, особливо в короткострокових дослідженнях. Один із принципів дослідження ЯЖ оснований на змінності показників ЯЖ у часі, які дозволяють здійснювати моніторинг стану хворого.

Таким чином, концепція та методологія дослідження ЯЖ створили можливості для вивчення різних аспектів життєдіяльності хворого і поставили нові питання і завдання з розробки подальших підходів до комплексної оцінки ЯЖ хворих із віддаленими наслідками бойової ЧМТ, проведення тестування нових інструментів досліджень. Традиційний медичний висновок, який зроблений лікарем, і оцінка за шкалами, дана самим хворим, складають об'єктивну характеристику стану здоров'я хворого. Об'єктивна інфрормація про якість життя дає реальну можливість пошуку 
шляхів підвищення профрілактики, ефективності лікування і розробку нових реабілітаційних програм [20]. Вивчається ефективність реабілітації 3 використанням різних оціночних шкал, чому присвячено багато робіт зарубіжних авторів [17, 23, 24]. За даними [22, 25], тільки $10 \% з$ числа осіб, які перенесли тяжку ЧМТ, отримували відновне лікування після гострого періоду.

У той же час, серед учасників реабілітаційних програм для осіб, які перенесли ЧМТ із будь-якою тяжкістю порушень, успішне їх виконання вдається лише у 50 \% пацієнтів [19, 22, 24, 25]. Інші результати, отримані в роботі автора [21], можливо, за рахунок більш індивідуально орієнтованих програм реабілітації. Більшість пацієнтів після виписування відзначали поліпшення: незалежні в самообслуговуванні - $84 \%$; у самостійному пересуванні - 82 \%; у встановленні соціальних зв'язків - $53 \%$; відновлення когнітивних функцій спостерігали в 41 \% випадків. Дані багатьох досліджень в цілому відображають помітне поліпшення фрізичних, когнітивних, емоційних та поведінкових показників і підтверджують необхідність впливу на процес лікування ЧМТ за допомогою системи реабілітації $[21,24]$. Існують різні підходи до реабілітації постраждалих із чМТ. Найкраще вивчені питання медичної реабілітації, причому особливо детально щодо порушення рухових фрункцій [12, 15]. Менш докладно вони розглядаються при інших наслідках ЧМТ, зокрема у хворих із цереброваскулярною патологією [9, 14, 15]. Потребують вдосконалення методи професійної, а особливо соціальної реабілітації хворих із наслідками ЧМТ.
Стосовно хворих із віддаленими наслідками чМТ потребує вдосконалення і адаптації використовувана на даний час індивідуальна програма реабілітації $[6,8]$. Програма не завжди враховує різноманітність клінічних синдромів, можливість реабілітації залежно від наявності прямих (переважно морфологічних) наслідків і опосередкованих (переважно судинних) в основному характеризуються прогресуючим перебігом. Розробці єдиного підходу до діагностики та лікування хворих із чМТ та їі наслідками сприяє і поширення неінвазивних методів діагностики (КТ та МРТ, ультразвукова доплерограсрія) $[1,3,6,14,18]$. Все це вже знаходить відображення в сучасній періодизації та класифікації наслідків ЧМТ, робить вплив на фрормування цілісної концепції травматичної хвороби головного мозку.

\section{Висновки}

Внаслідок зростання кількості військових конфрліктів у світі та розвитку військових технологій спостерігається тенденція до зростання кількості черепно-мозкових травм. Удосконалення підходів до лікування цих травм дозволило збільшити рівень виживання хворих, проте внаслідок цього зросла i медико-соціальна значимість удосконалення системи лікування віддалених їх наслідків, що внаслідок значного рівня неврологічних, когнітивних та адаптаційних порушень, мають значний негативний вплив на якість життя хворих та їх оточення, викликаючи негативні соціальні наслідки для суспільства в цілому.

Перспективи подальших досліджень полягають у вивченні якості життя та наслідків черепномозкових травм в учасників бойових дій в зоні антитерористичної операції в Україні.

\section{Список літератури}

1. Артарян А. А. К периодизации черепно-мозговой травмы у детей / А. А. Артарян, О. Б. Гаевый, А. Г. Королев // Вопросы нейрохирургии. - 1990. - № 6. - С. 16-18.

2. Бабенко А. И. Социологическая оценка организации медицинской помощи при черепно-мозговой травме / А. И. Бабенко, Г. Г. Орехова // Проблемы социальной гигиены, здравоохранения и истории медицины. - 2003. № 5. - C. 40-42.

3. Гиткина И. С. Состояние трудоспособности после острой черепно-мозговой травмы / И. С. Гиткина, Ф. В. Олешкевич, А. М. Климович // Вопросы нейрохирургии. - 1992. - № 1. - С. 11-15.

4. Каримов P. X. Эпидемиологические аспекты своевременности оказания медицинской помощи пострадавшим с черепно-мозговой травмой / Р. Х. Каримов, В. И. Данилов, В. П. Панкова // Неврологический вестник. - 2006. Вып. 1-2. - С. 43-48.

5. Квасницкий Н. В. Диагностика отдаленных последствий легкой черепно-мозговой травмы с учетом клинического симптомокомплекса / Н. В. Квасницкий, А. А. Скляр, В. И. Смоланка // Нейрохирургия: сб. науч. тр. - 1989. Вып. 22. - С. 38-140.

6. Квасов В. Т. Черепно-мозговая травма / В. Т. Квасов, Н. А. Кудрина // Клиническая геронтология. - 2004. - № 8. C. 56-59.

7. Клиническое руководство по черепно-мозговой травме ; под ред. А. Н. Коновалова, Л. Б. Лихтермана, А. А. Потапова. - М. : АНТИДОР, 1998-2001. - Загл. обл. : Черепно-мозговая травма : клиническое руководство. T. 1. $-1998 .-550 \mathrm{c}$.

8. Кондаков Е. Н. Черепно-мозговая травма: руководство для врачей неспециализированных стационаров / Е. Н. Кондаков, В. В. Кривецкий. - СПб. : СпецЛит, 2002. - 271 с.

9. Коновалов А. Н. Травма центральной нервной системы : отраслевая науч.-техн. программа / А. Н. Коновалов, Л. Б. Лихтерман, А. В. Лившиц // Вопросы нейрохирургии. - 1986. - № 2. - С. 3-8.

10. Коновалов А. Н. Нейротравматология: справ. ; под ред. А. Н. Коновалова. - М. : ВАЗАР-ФСРРО, $1994 .-416$ с.

11. Косинец А. Н. Непроизводственный городской травматизм как медико-социальная проблема / А. Н. Косинец, В. П. Дейкало, М. А. Никольский // Новые технологии в военно-полевой хирургии и хирургии повреждений мирного времени : материалы междунар. конфр. - СПб., 2006. - С. 336-337. 
12. Лебедев В. В. Руководство по неотложной нейрохирургии / В. В. Лебедев, Л. Д. Быковников. - М. : Медицина, 1987. $-336 \mathrm{c}$.

13. Лебедев В. В. Неотложная нейрохирургия : руководство для врачей / В. В. Лебедев, В. В. Крылов. - М. : Медицина, 2000. - 567 с.

14. Лебедев Э. Д. Основные дефекты организации медицинской помощи больным с острой черепно-мозговой травмой в крупном городе / Э. Д. Лебедев // Бюл. Укр. ассоциации нейрохирургов. - 1998. - № 5. - С. 71.

15. Лихтерман Б. Черепно-мозговая травма. Что делать? / Б. Лихтерман // Медицинская газета. - 2009. - № 11.

16. Морозов В. В. Отдаленные последствия легкой черепно-мозговой травмы / В. В. Морозов, Ю. А. Воробьев, В. В. Посохов // Нейрохирургия : сб. науч. тр. - 1989. - Вып. 22. - С. 45-48.

17. Полищук Н. Е. Черепно-мозговая травма в пожилом и старческом возрасте / Н. Е. Полищук // Нейротравматология : сб. науч. тр. - М., 1994. - С. 202-204.

18. Помников В. Г. Особенности клиники, реабилитации и организации медико-социальной экспертизы больных с цереброваскулярной патологией, перенесших закрытую черепно-мозговую травму / В. Г. Помников, А. Ю. Макаров // Обзорная информация. - М. : ЦБНТИ. - 2000. - Вып. 19. - 28 с.

19. Черненко І. І. Особливості проявів клінічної картини наслідків перенесеної бойової черепно-мозкової травми / І. І. Черненко // Вісник наукових досліджень. - 2011. - № 4 (65). - С. 142-145.

20. Черненко И. И. Развитие цереброваскулярных нарушений у лиц с последствиями боевой черепно-мозговой травмы / И. И. Черненко // Міжнародний медичний журнал. - 2011. - Т. 17, № 4 (68). - С. 21-25.

21. Черненко І. І. Сучасні методи психологічної терапії хворих із посттравматичними стресовими розладами в контексті їх медико-соціального значення / І. І. Черненко, І. А. Чухно// Міжнародний неврологічний журнал. - 2017. № 5 (91). - C. 112-115.

22. Brett E. A. Imagary and posttraumatic stress disorder: an overview / E. A. Brett, R. Ostroff // Amer. J. Psychiatry. 1985. - Vol. 142. - P. 417- 424.

23. Brooks N. Psychosocial assessment after traumatic brain injury / N. Brooks // Scand. J. Rehab. Med.. - 1992. Vol. 26. - P. 126-131.

24. Wilson J. T. L. Emotional and cognitive consequences of head injury in relation to the Glasgow outcome scale I J. T. L. Wilson, L. E. L. Pettigrew, G. M. Teasdale // J. Neurol. Neurosurg. Psych. - 2000. - Vol. 69. - P. $204-209$.

25. Zafonte R.D. Functional outcome after violence related traumatic brain injury / R. D. Zafonte, N. R. Mann, S. R. Millis // Brain Injury. - 1997. - Vol. 11, № 6. - P. 403

\section{References}

1. Artarian, A.A., Gayev, O.B., \& Korolyov A.G. (1990). K periodizatsii cherepno-mozgovoy travmy u detey [On the periodization of craniocerebral trauma in children Artaryan]. Voprosy neyrokhirurgii - Questions of Neurosurgery, 6, 16-18 [in Russian].

2. Babenko, A.I. \& Orekhova G.G. (2003). Sotsiologicheskaya otsenka organizatsii meditsinskoy pomoshchi pri cherepnomozgovoy travme [Sociological assessment of the organization of medical care in cases of craniocerebral trauma]. Problemy sotsialnoy gigiyeny, zdravookhraneniya i istorii meditsiny - Problems of Social Hygiene, Health and History of Medicine, 5, 40-42 [in Russian].

3. Gitkina, I.S., Oleshkevich, F.V., \& Klimovich A.M. (1992). Sostoyaniye trudosposobnosti posle ostroy cherepno-mozgovoy travmy [State of working capacity after acute craniocerebral injury]. Voprosy neyrokhirurgii - Questions of Neurosurgery, 1, 11-15 [in Russian].

4. Karimov, R.Kh., Danilov, V.I., \& Pankova, V.P. (2006). Epidemiologicheskiye aspekty svoyevremennosti okazaniya meditsinskoy pomoshchi postradavshim s cherepno-mozgovoy travmoy [Epidemiological aspects of the timeliness of medical care for victims with craniocerebral trauma]. Nevrologicheskiy vestnik - Neurological Herald, 1-2, $43-48$ [in Russian].

5. Kvasnitskiy, N.V., Sklyar, A.A. \& Smolanka V.I. (1989). Diagnostika otdalennykh posledstviy legkoy cherepnomozgovoy travmy s uchetom klinicheskogo simptomokompleksa [Diagnosis of the long-term consequences of mild craniocerebral trauma in view of the clinical symptom complex]. Neyrokhirurgiya - Neurosurgery, 22, 38-140 [in Russian].

6. Kvasov, V.T. \& Kudrina N.A. (2004). Cherepno-mozgovaya travma [Craniocerebral injury]. Klinicheskaya gerontologiya Clinical Gerontology, 8, 56-59 [in Russian].

7. Konovalov, A.N., Likhterman, L.B. \& Potapov A.A. (Eds.). (1998). Klinicheskoye rukovodstvo po cherepno-mozgovoy travme [Clinical guidelines for traumatic brain injury]. Moscow: ANTIDOR [in Russian].

8. Kondakov Ye.N., \& Krivetskiy V.V. (2002). Cherepno-mozgovaya travma: rukovodstvo dlya vracheynespetsializirovannykh statsionarov [Craniocerebral trauma: a guide for physicians in non-specialized hospitals]. SPb.: SpetsLit [in Russian].

9. Konovalov, A.N., Likhterman, L.B. \& Livshits, A.V. (1986). Otraslevaya nauchno-tekhnicheskaya programma «Travma tsentralnoy nervnoy sistemy» [Branch scientific and technical program "Trauma of the central nervous system"]. Voprosy neyrokhirurgii - Questions of Neurosurgery, 2, 3-8 [in Russian].

10. Konovalov A.N. (Ed.). (1994). Neyrotravmatologiya [Neurotraumatology]. Moscow: VAZAR-FSRRO [in Russian].

11. Kosinets, A.N., Deykalo, V.P. \& Nikolskiy M.A. (2006). Neproizvodstvennyy gorodskoy travmatizm kak medikosotsialnaya problema [Non-productive urban injuries as a medical and social problem]. Proceeding from MIIM `06: Novyye tekhnologii $v$ voyenno-polevoy khirurgii i khirurgii povrezhdeniy mirnogo vremeni - New technologies in military field surgery and surgery of peacetime damages. (pp. 336-337). Saint-Petersburg [in Russian].

12. Lebedev, V.V. \& Bykovnikov, L.D. (1987). Rukovodstvo po neotlozhnoy neyrokhirurgii [Manual on urgent neurosurgery]. Moscow: Meditsina [in Russian].

13. Lebedev, V.V. \& Krylov, V.V. (2000). Neotlozhnaya neyrokhirurgiya [Emergency neurosurgery]. Moscow: Meditsina [in Russian]. 
14. Lebedev E.D. (1998). Osnovnyye defekty organizatsii meditsinskoy pomoshchi bolnym s ostroy cherepno-mozgovoy travmoy $v$ krupnom gorode [The main defects in the organization of medical care for patients with acute craniocerebral trauma in a large city]. Byulleten Ukrainskoy assotsiatsii neyrokhirurgov - Bulletin of the Ukrainian Association of Neurosurgeons, 5, 71 [in Ukrainian].

15. Likhterman, B. (2009). Cherepno-mozgovaya travma. Chto delat? [Craniocerebral injury. What to do?]. Meditsinskaya gazeta - Medical Newspaper, 11 [in Russian]

16. Morozov, V.V., Vorobiev, Yu.A., \& Posokhov V.V. (1989). Otdalennyye posledstviya legkoy cherepno-mozgovoy travmy [Long-term effects of mild craniocerebral trauma]. Neyrokhirurgiya - Neurosurgery, 22, 45-48 [in Russian].

17. Polishchuk, N.Ye. (1994). Cherepno-mozgovaya travma v pozhilom i starcheskom vozraste [Craniocerebral injury in elderly and senile age]. Neyrotravmatologiya - Neurotraumatology, 202-204 [in Russian].

18. Pomnikov, V.G. \& Makarov, A.Yu. (2000). Osobennosti kliniki, reabilitatsii i organizatsii mediko-sotsialnoy ekspertizy bolnykh s tserebrovaskulyarnoy patologiyey, perenesshikh zakrytuyu cherepno-mozgovuyu travmu [Features of the clinic, rehabilitation and organization of medical and social examination of patients with cerebrovascular pathology who underwent a closed craniocerebral trauma]. Obzornaya informatsiya - Review Information, 19 [in Russian].

19. Chernenko, I.I. (2011). Osoblyvosti proiaviv klinichnoi kartyny naslidkiv perenesenoi boyovoi cherepno-mozkovoi travmy [Features of the manifestations of a clinical picture of the consequences of a transient craniocerebral trauma]. Visnyk naukovykh doslidzhen - Bulletin of Scientific Researches, 4 (65), 142-145 [in Ukrainian].

20. Chernenko, I.I. (2011). Razvitiye tserebrovaskulyarnykh narusheniy u lits s posledstviyami boyevoy cherepnomozgovoy travmy [Development of cerebrovascular disorders in persons with consequences of an armed craniocerebral trauma]. Mízhnarodnyi medychnyi zhurnal - International Medical Journal, 17, 4 (68), 21-25 [in Russian].

21. Chernenko, I.I., \& Chukhno, I.A. (2017). Suchasni metody psykholohichnoi terapii khvorykh iz posttravmatychnymy stresovymy rozladamy $v$ konteksti yikh medyko-sotsialnoho znachennia [Modern methods of psychological therapy of patients with post-traumatic stress disorder in the context of their medical and social significance]. Mizhnarodnyi nevrolohichnyi zhurnal - International Neurological Journal, 5 (91), 112-115 [in Ukrainian].

22. Brett, E.A., \& Ostroff, R. (1985). Imagary and posttraumatic stress disorder: an overview. Amer. J. Psychiatry, 142, $417-424$. 23. Brooks, N. (1992). Psychosocial assessment after traumatic brain injury. Scand. J. Rehab. Med., 26, 126-131.

24. Wilson, J.T.L., Pettigrew, L.E.L., \& Teasdale, G.M. (2000). Emotional and cognitive consequences of head injury in relation to the Glasgow outcome scale. J. Neurol. Neurosurg. Psych., 69, 204-209.

25. Zafonte, R.D., Mann, N.R., Millis, S.R., Wood, D.L., Lee, C.Y., \& Black, K.L. (1997). Functional outcome after violence related traumatic brain injury. Brain Injury, 11 (6), 403.

\section{ЭПИДЕМИОЛОГИЧЕСКИЕ И КЛИНИЧЕСКИЕ АСПЕКТЫ ПОСЛЕДСТВИЙ ЧЕРЕПНО-МОЗГОВОЙ TPABMЫ}

И.И. Черненко, И.А. Чухно

Харьковский национальный медицинский университет, г. Харьков, Украина

Цель: провести исследование распространенности черепно-мозговой травмы и ее основных последствий на основании изучения литературных источников, влияния патологии на качество жизни больных, социальную значимость этих последствий с учетом распространенности патологии.

Материалы и методы. В исследовании использовали библиосемантический и аналитический методы, метод научного абстрагирования. Были исследованы статистические данные и научные публикации по вопросам распространенности и последствий черепно-мозговых травм, особенностей реабилитации.

Результаты. Проведенный анализ распространенности черепно-мозговых травм, их отдаленных последствий позволяет констатировать рост значимости этой проблемы на современном этапе развития государства, а их влияние на качество жизни больных, сложности в дальнейшей социальной адаптации пациентов о росте медико-социальной значимости этой проблемы.

Выводы. В результате роста количества военных коноликтов в мире и развития военных технологий наблюдается тенденция к росту числа черепно-мозговых травм. Совершенствование подходов к лечению этих травм позволило увеличить выживаемость больных, однако вследствие этого возросла и медикосоциальная значимость совершенствования системы лечения отдаленных их последствий, которые вследствие значительного уровня неврологических, когнитивных и адаптационных нарушений, имеют существенное негативное влияние на качество жизни больных и их окружения, вызывая негативные социальные последствия для общества в целом.

КЛЮЧЕВЫЕ СЛОВА: черепно-мозговая травма; медико-социальные последствия.

\section{EPIDEMIOLOGICAL AND CLINICAL ASPECTS OF THE CRANIOCEREBERAL TRAUMA}

I.I. Chernenko, I.A. Chukhno

Kharkiv National Medical University, Kharkiv, Ukraine

Purpose: to conduct a study on the prevalence of craniocerebral trauma and its main effects on the basis of studying literary sources, their impact on the quality of life of patients, and the social significance of these effects in the light of the prevalence of pathology. 
Materials and Methods. The study used bibliosemantic and analytical methods, the method of scientific abstraction. The statistical data and scientific publications about the incidence and consequences of craniocerebral trauma, their remote consequences and the features of rehabilitation were studied.

Results. The analysis of the prevalence of craniocerebral traumas, their remote consequences allows us to ascertain the growth of the significance of these problems at the present stage of the state's development, and their impact on the quality of life of patients, the difficulties in their further social adaptation of the growth of the medical and social significance of this problem.

Conclusions. As a result of the growing number of military conflicts in the world and the development of military technology, there is a tendency to increase the number of craniocerebral injuries. Improvement of approaches to the treatment of these injuries has made it possible to increase the survival rate of patients, however, due to this, the medical and social significance of improving the system of treating their long-term consequences, which due to a significant level of neurological, cognitive and adaptive disorders, has a significant negative impact on the quality of life of patients and their environment, causing negative social consequences for society as a whole.

KEY WORDS: craniocerebral trauma; medical and social consequences.

Рукопис надійшов до редакції 01.11.2017 р.

Відомості про авторів:

Черненко Інна Іванівна - кандидат медичних наук, старший викладач кафедри громадського здоров'я та управління охороною здоров'я Харківського національного медичного університету; тел.: +38(057) 707-73-20. Чухно Інна Анатоліївна - к. держ. управління, доцент кафедри громадського здоров'я та управління охороною здоров'я Харківського національного медичного університету; тел.: +38(057) 707-73-20. 